\title{
PROCESSO DE DECISÃO DOS CONSUMIDORES QUANTO A CONCESSÃO DOS RECURSOS HÍDRICOS NO MUNICÍPIO DE CAPIVARI: UM ESTUDO A PARTIR DA TEORIA DOS JOGOS
}

\author{
Valdir Antonio Vitorino Filho \\ Doutorando em Administração da Universidade Metodista de Piracicaba - UNIMEP \\ valdirxadrez@bol.com.br \\ Mário Sacomano Neto \\ Doutor em Engenharia de Produção pela Universidade Federal de São Carlos - UFSCAR \\ Professor da Universidade Metodista de Piracicaba - UNIMEP \\ msacomano@unimep.br \\ Eliciane Maria da Silva \\ Doutora em Engenharia de Produção pela Escola de Engenharia de São Carlos Universidade de São Paulo - \\ USP \\ Professor da Universidade Metodista de Piracicaba - UNIMEP \\ elicianems@unimep.br
}

\section{RESUMO}

Este estudo tem como objetivo analisar o comportamento dos consumidores e a decisão do poder Executivo quanto à concessão dos recursos hídricos no município de Capivari, a partir da Teoria dos Jogos. Tendo como hipóteses: o Equilíbrio de Nash ocorre com o aceite e cooperação da população para a decisão final da prefeitura; um cenário de concessão dos recursos hídricos no município de Capivari trará desconforto da população consumidora da água; e para a prefeitura é indiferente a opinião dos consumidores para tomada de decisão com relação à concessão ou não dos recursos hídricos. A pesqui sa é classificada como: exploratória e descritiva e foi realizada em uma etapa qualitativa e outra quantitativa. $\mathrm{Na}$ primeira etapa foram realizadas entrevistas em profundidade com os Poderes Legislativo e Executivo do município de Capivari, e posteriormente aplicação de questionários com 200 consumidores, com análise estatística básica de frequiência, média e desvio padrão. Finalmente, obtevese que os consumidores são contra a concessão do SAAE, mas também discordam dos serviços oferecidos pela autarquia atualmente, e o Poder Público não leva em consideração a opinião dos consumidores quanto à concessão.

Palavras-Chave: Recursos Hídricos; Teoria dos Jogos; Gestão Pública; Equilíbrio de Nash.

\section{CONSUMER DECISION PROCESS FOR THE ALLOCATION OF WATER RESOURCES IN THE CITY OF CAPIVARI: A STUDY FROM GAME THEORY}

\begin{abstract}
The objective of this study is to analyze the behavior of the consumers and the decisions of the Executive power relative to the concession of the hídricos resources in the city of Capivari, from the Theory of the Games. The hypothesis is that the Balance of Nash occurs with the acceptance and cooperation of the population with the final decision belonging to city hall. A concession of the hidrics resources in the city of Capivari will bring discomfort to the consumers of the water and if the city hall is indifferent to the opinion of the consumers that will affect their decision with regard to the concession or not of the hidrics resources. The research is classified as exploratory and descriptive and was performed through a qualitative stage as well as a quantitative one. In the first stage in depth interviews were conducted with Legislatures and Executives of the city of Capivari, and questionnaires were completed with 200 consumers, with analysis of basic statistics such as frequency, average and shunting line standard. It was revealed that the consumers are against the concession of the SAAE but also disagree with the services offered for the government currently and the Public Power does not take in consideration the opinion of the consumers about the concession.
\end{abstract}

Keywords: Water resources. Theory of the Games. Concession. Public administration. Nash Equilibrium.

Revista de Gestão Social e Ambiental - RGSA, São Paulo, v. 5, n. 2, p. 187-210 mai./ago. 2011. 


\section{INTRODUÇÃO}

O estudo de decisões interativas envolve pessoas afetadas tanto pelas suas próprias escolhas quanto pelos outros. Esse estudo baseia-se em dois princípios: primeiro as escolhas das pessoas são motivadas por preferências bem definidas e estáveis, ou seja, leva em consideração a relação entre as suas escolhas e as decisões dos outros. Onde os jogadores têm escolhas definidas, tomando por base as preferências dos demais jogadores. O segundo princípio baseia-se em um modelo de teoria dos jogos que estuda o comportamento estratégico dos agentes, os quais tomam decisões, baseados em objetivos bem definidos e no seu conhecimento ou nas suas expectativas sobre o comportamento dos outros agentes.

Essa pesquisa traz uma proposta de relacionar o Poder Público, no campo dos recursos hídricos, com Teoria dos Jogos, principalmente com a elaboração dos cenários de interação entre os consumidores e os Poderes legislativo e Executivo, na busca por um equilíbrio de Nash.

A Teoria dos Jogos mostra que, em jogos de apenas um jogador, a estratégia é determinada exclusivamente pelas regras do próprio jogo. O que não é o caso desse estudo, pois existem vários jogadores envolvidos: os poderes Executivo e Legislativo, e a população consumidora de água.

Em jogos com dois ou mais jogadores, que é o caso de estudo, cada jogador leva em consideração as possíveis estratégias do outro. Como por exemplo: levar em consideração a opinião dos consumidores para a criação ou aprovação de leis que regem e regulam a sociedade. Diz-se que esses jogos são de soma zero: uma das partes perde exatamente o que a outra ganha, exemplo: o consumidor paga impostos e o poder público arrecada os impostos pra a administração.

Por outro lado, o objeto de estudo é o município de Capivari-SP, que está em processo de decisão de conceder ou não às empresas privadas o gerenciamento dos recursos hídricos do município. Como apresentado, os Poderes Executivo e Legislativo podem ter seu comportamento orientado, pelo comportamento coletivo dos munícipes, sendo influenciado pela opinião da população.

Neste cenário pode haver jogos cooperativos e jogos não cooperativos, esta distinção é importante, pois em jogos não cooperativos, apenas um equilíbrio de Nash representará um resultado de ganho para ambas as partes.

Para Nash (1950) essa distinção é importante, um jogo cooperativo é aquele formado em acordos entre jogadores, estritamente exigíveis por ambos. Devido ao equilíbrio de Nash representar uma situação na qual a estratégia utilizada por ambos os jogadores é a melhor resposta à estratégia do outro jogador, de forma que nenhuma concessionária que assumir a autarquia terá incentivos para mudar suas estratégias.

Diante do problema apresentado a respeito do município de Capivari e baseando-se na teoria dos jogos, principalmente, no equilíbrio de Nash, este estudo busca responder as seguintes questões de pesquisa: o comportamento do consumidor influencia nas decisões do Poder Executivo e Legislativo para a tomada de decisão no setor de recursos hídricos? Para haver um equilíbrio de Nash no caso das decisões de prefeitura e população quais ações devem ser adotadas para que ambos ganhem nesse jogo? Se a população for à favor das decisões que a prefeitura do município de Capivari adotar, será suficiente para haver equilíbrio de Nash?

A fim de responder esses questionamentos, a presente pesquisa tem o objetivo de analisar o comportamento dos consumidores e a decisão do poder Executivo quanto à concessão dos recursos hídricos no município de Capivari, a partir da Teoria dos Jogos e conforme cenários elaborados.

A pesquisa é classificada como: exploratória e descritiva e foi realizada em uma etapa qualitativa e outra quantitativa. Na primeira etapa foram realizadas entrevistas preliminares e em profundidade com os Poderes Legislativo e Executivo do município de Capivari, e posteriormente aplicação de questionários com 200 consumidores, com análise estatística descritiva, usando a frequiência, média e desvio padrão.

Revista de Gestão Social e Ambiental - RGSA, São Paulo, v. 5, n. 2, p. 187-210 mai./ago. 2011. 
A análise desse estudo deve levar em conta: a percepção e a expectativa do consumidor (população de Capivari), o agente (prefeitura) que decide se haverá concessão ou não, as estratégias que serão adotadas a partir de uma escolha racional ou não. Possivelmente estabelecendo a hipótese ou cenário ideal para ambas as partes.

O SAAE (Serviço Autônomo de Água e Esgoto) encontra-se em situação grave: com falta de captação de água, falta de capacidade para reservação, déficit financeiro há anos, dívidas, falta de capacidade de investimentos, sistema de medição de consumo totalmente obsoleto, sistema de cobrança ineficiente, inadimplência superior a 40\%, obras das ETEs (Estações de Tratamento de Esgoto) abandonadas pelas construtoras, sistema de gestão não profissional e inseguro, veículos e equipamentos sucateados. (SAAE, 2009).

\section{REVISÃO TEÓRICA, HIPÓTESES E CENÁRIOS DA PESQUISA}

\subsection{Teoria dos Jogos}

No século XX, os matemáticos John Von Neumann (1903 - 1957) e Oskar Morgenstern (1902 -1977) lançaram as bases de uma Teoria dos Jogos, no livro Theory of Games and Economic Behavior (Teoria dos Jogos e Comportamento Econômico, publicado em 1944) que interpretava as escolhas racionais e os acontecimentos sociais por meio dos modelos de jogos de estratégia de ação que lhes fossem mais vantajosas de acordo com um cálculo acerca de sua probabilidade e satisfação máxima de sua utilidade.

Para Carneiro (1981) a sobrevivência da raça humana sempre esteve atrelada a cooperação, desde o início das civilizações. A palavra cooperação provém do latim cooperatione, derivado do verbo cooperati, de cum + operari = operar, trabalhar em conjunto (PINHO, 1997).

$\mathrm{Na}$ mesma idéia Nash (1950) descreve a versão econômica de Teoria dos Jogos disseminando a cooperação em diversos setores da economia, sendo reconhecido em todos os países como a maneira mais adequada, participativa, justa, democrática para atender as necessidades da população. A importância de se aprofundarem os estudos neste setor tem por base conhecer, analisar e estudar estratégias que passam a ser usadas para um crescimento considerável, propiciando assim uma opção de êxito e minimização das disparidades na obtenção de resultados.

A forma com que a cooperação deve ser encarada pelas organizações é, de maneira, a criar uma visão integradora que se encontra acima de conceitos políticos-ideológicos de qualquer natureza (AUMANN, 1964 e SCHELING, 1958).

Para Day e Reibstein (1997) as organizações devem escolher estratégias de equilíbrio, visando buscar três características: estabilidade, caráter ideal e racionalidade. Em suma, cada indivíduo acredita estarem fazendo o melhor possíveis dadas às ações dos outros.

Para que a sociedade humana funcione é necessário criar o mecanismo do ostracismo, em que o indivíduo não cooperativo seja excluído do grupo ou da organização da qual faz parte. Para isso criou-se o estigma, que é uma marca que o indivíduo "condenado" ao ostracismo carrega para ser facilmente identificados pelos demais jogadores ao longo do tempo.

Alguns estudos sugerem critérios preliminares para avaliação da estratégia (Tilles, 1983; Christiensen, 1978) como: sua clareza, impacto motivacional, consistência material, compatibilidade com o meio ambiente, adequação à luz dos recursos, grau de risco, equiparação aos valores pessoais de figuras exponenciais, horizonte de tempo e praticidade.

Trivers (1971) formula a teoria do altruísmo recíproco, onde há uma forma simplificada de encarar o mundo vivo que é a de "uma mão lava a outra". Pode-se qualificar de altruísmo aquilo que fazemos com vistas na retribuição futura, sempre com a sensação de que sobre a pele de "cordeiro" do altruísmo vê-se o "lobo" egoísta. As organizações amparadas pela Teoria dos Jogos parece identificarem um fundo de interesses em qualquer gesto desprendido.

Revista de Gestão Social e Ambiental - RGSA, São Paulo, v. 5, n. 2, p. 187-210 mai./ago. 2011. 
Fiani (2006) exemplifica cooperação com o exemplo das pequenas lojas que se unem (poder de negociação com fornecedores, menores custos e outros benefícios) para poder competirem em nível igual no varejo e não serem "engolidos" pelas grandes redes.

\subsubsection{Equilíbrio de Nash}

No modelo desenvolvido por Nash (1950) os bens não são objetos imediatos de sua utilidade, mas têm associação com um conjunto de atributos diretamente relevantes para o consumidor (qualidade, rapidez, preço, percepção e expectativa). Nessa formulação, a função utilidade é função do conjunto de atributos ou características, obtidas através de uma série de produtos e serviços oferecidos em conjunto.

Em um Equilíbrio de Nash cada jogador escolhe uma ação com base nas ações tomadas pelos outros jogadores. Para definir a solução do jogo é importante eliminar ações que um jogador definitivamente não tomaria. Em um jogo entre dois ou mais jogadores é particularmente atraente assumir que os jogadores, procurando por modos de simplificar a situação com que se deparam, adotarão uma tática a seguir. Assume-se que os jogadores excluem de consideração ações que não são respostas ótimas para o que quer que seja que os outros façam. Um jogador que sabe que os outros jogadores são racionais pode assumir que eles também irão excluir tais ações de consideração.

No jogo da concessão dos recursos hídricos, um jogador que sabe que os outros jogadores são racionais, não escolheria uma ação que não fosse uma resposta ótima para o que quer que fosse que os outros fizessem. Além disso, um jogador que sabe que os outros jogadores sabem que ele é racional, pode argumentar que eles também não escolherão ações que nunca são ótimas respostas a concessão ou não dos recursos.

Um problema que pode surgir quando se usa a eliminação de estratégias, para obtenção do equilíbrio de Nash é que o processo frequientemente produz uma predição muito imprecisa sobre a jogada. Onde podem haver estratégias fracamente dominadas a serem eliminadas, por exemplo: conceder os serviços com a população sendo contra.

Se existe um modo óbvio de jogar, então esse modo é um Equilíbrio de Nash, pois é o que traz melhores resultados ao longo prazo, não fornecendo prejuízo a nenhum dos jogadores. Entretanto nem todo equilíbrio de Nash é um modo óbvio de se jogar. Às vezes, se os jogadores podem se comunicar antes do jogo é de interesse comum coordenar suas ações.

Do mesmo modo, ocorre com o poder público, quando os consumidores têm uma opinião e perspectivas diferentes as que pretendem ser oferecidas, e os mesmos têm maior poder de influência no jogo, se o tomador de decisão (prefeitura) não realizar ações a contento para corrigir ou alterar essa situação o Equilíbrio de Nash deixa de existir. Formando uma curva constante de escolhas durante um período de tempo, onde o poder público deve-se adequar as exigências dos consumidores e os consumidores devem se adequar as decisões do poder público, sempre na busca constante de um Equilíbrio de Nash. Porém o equilíbrio não é uma constante fácil de conseguir, muito menos se manter. São necessárias as mudanças ao longo do tempo para que ambas as partes continuem sempre ganhando nesse jogo dos recursos hídricos contra percepções e expectativas dos consumidores.

\subsection{A Água e Concessão dos Recursos Hídricos}

Existem várias espécies de concessão, destacando-se como principais a concessão de serviço público, concessão de obra pública, concessão de uso de bem público e concessão de execução de obra ou serviço público. Nessa pesquisa interessa-se na concessão de serviço público. Antes, porém, implica delimitar qual o conceito de "bem" e "serviço público". 
Segundo Santos (2004) o conceito de bem público abrange tudo aquilo que possua valor econômico e obtenha proteção jurídica. Para Silva (2005) os bens de domínio público são de uso comum de toda a população. Já os bens do patrimônio administrativo são de uso especial.

Para Silva (2005) o serviço público é diferente dos serviços comuns prestados pelas empresas privadas ou pelos prestadores autônomos, sendo que este está subordinado ao coletivo, portanto, um interesse maior que o interesse individual de cada cidadão. Assim, o Estado, por critérios jurídicos, técnicos e econômicos, define e estabelece quais os serviços deverão ser públicos ou de utilidade pública.

Santos (2004) acredita que na execução de obra pública, é comum a influência de três fatores, que por sua vez, prejudicam o cumprimento do contrato de execução exatamente nos termos em que foi redigido pelas partes. Primeiro é a necessidade de serem efetuadas alterações e adaptações no projeto original. Segundo é o atraso nas desapropriações de imóveis que serão afetados de alguma maneira pela construção. O terceiro é o atraso na disponibilização dos recursos financeiros previstos no orçamento.

Segundo Critsinelis (2003) a concessão de serviço público pode ser entendida como a delegação contratual da execução de um serviço, de forma autorizada e regulamentada por contratos. Através das concessões de serviços públicos que o município atribui o exercício de um serviço público a alguém que deseja prestá-lo, por conta própria e risco, nas condições fixadas pelo Poder Público Municipal.

Já Silva (2005) salienta que o município concedente não transfere propriedade alguma ao concessionário, nem se despoja de qualquer direito ou prerrogativa pública, mas sim delega a execução do serviço, nos limites e condições legais ou contratuais.

De acordo com Junqueira (2004) o ponto de vista econômico, água e petróleo pertenciam, as categorias com valores incomparáveis. O combustível é um resíduo fóssil, que existe em quantidade esgotáveis e cuja extração requer investimentos pesados. A água é um recurso renovável pelo ciclo natural da evaporação-chuva e distribuído com fartura na superfície do Planeta. Ocorre que a intervenção humana afetou de forma dramática o ciclo natural de renovação dos recursos hídricos. Em certas regiões do mundo, como o oeste dos Estados Unidos, o norte da China e boa parte da Índia, a água vem sendo consumida em ritmo mais rápido do que se pode renovar. Mais da metade dos rios está poluída pelos despejos de esgotos, resíduos industriais e agrotóxicos.

Segundo a ONU (2009) estima-se que 30\% das maiores bacias hidrográficas perderam mais da metade da cobertura vegetal original, o que levou à redução da quantidade de água. Nove de cada 10 litros de água utilizados no terceiro mundo são devolvidos à natureza sem nenhum tipo de tratamento. Por causa disso, o conceito de água inesgotável e gratuita da natureza é coisa do passado.

Uma das recomendações do DAEE (2009) e da ONU (2009) para reduzir o desperdício é considerar a água como uma mercadoria, com preço de mercado. A Organização para Alimentação e Agricultura das Nações Unidas (FAO) estima uma perda de $60 \%$ da água nos projetos de irrigação. Isso numa atividade, a agricultura, que consome $70 \%$ de toda a água doce usada em escala mundial. No Texas, um dos Estados mais secos dos EUA, o aumento no custo da água levou os fazendeiros a trocar os sistemas de irrigação antigos, com aproveitamento de $50 \%$ do líquido, por outros mais modernos, com perdas de apenas 5\%. O mesmo raciocínio vale para as regiões urbanizadas. Na Europa, em países como a França, a Alemanha e a Holanda, cobra-se cerca de 0,17 centavo de dólar pára cada metro cúbico de água (1.000 litros), sem contar as tarifas de abastecimento e tratamento de esgoto.

Segundo Garrido (2000) é preciso melhorar a rede de distribuição, tanto para a agricultura como para a região urbana. Nos países industrializados, a perda de água é causada por sistemas obsoletos de distribuição. No Terceiro Mundo, o problema á a falta de esgotos e de água encanada.

Segundo ANA (2009) atualmente há tecnologia para a reciclagem de água. A cidade de Durban, na África do Sul, por exemplo, trata o esgoto doméstico e revende a água para uso 
industrial. Isso significa uma economia de $10 \%$ do volume de água utilizado. Também é preciso diminuir a captação dos lençóis freáticos, que estão sendo exauridos além da capacidade de recuperação. Há quarenta anos, poços de 30 metros de profundidade eram suficientes para atingir o aquífero de Ogallala, o enorme depósito subterrâneo de água doce sob oito estados Americanos. Atualmente, é necessário perfurar 100 metros. Uma coisa é certa: a água é uma mercadoria de valor crescente. Estima-se que a indústria encarregada de captar a água das fontes, entregá-la na torneira do consumidor e tratá-la antes que volte a natureza movimente 400 bilhões de dólares, entre empresas públicas e privadas. Isso equivale a $40 \%$ do setor petrolífero e é de $30 \%$ maior que o setor farmacêutico. Como o petróleo no passado, a água está no cerne de um número cada vez maior de tensões internacionais.

A ONU (2009) calcula que 300 rios são objetos de conflito fronteiriços. Uma controvérsia séria envolve a disputa entre três países do Oriente Médio pelo uso das águas do Eufrates. A Turquia, onde está à cabeceira do curso de água, ergueu-se várias represas para projetos de irrigação.

Dowbor e Tagnin (2005) o desperdício é grande e nós somente percebemos como a água faz falta quando as torneiras secam, pois fomos acostumados a tê-la em abundância e a custo baixo.

Tucci (2003), Tundisi (2003) e Vargas (1999) garantem: “a água será o petróleo do futuro". A escassez da água está se tornando uma das preocupações de políticos, ambientalistas e empresários. Nos Estados Unidos algumas prefeituras da Califórnia impuseram um racionamento de água à população a fim de garantir que o fornecimento não fosse interrompido. Cerca de $70 \%$ dos rios e lagos da China estão poluídos e mais da metade das cidades apresenta problemas de abastecimento. A escassez de água atinge $20 \%$ da população mundial, com perspectivas de chegar a $33 \%$ até 2025, segundo o último relatório das Nações Unidas sobre o tema.

Para Rebouças (1999) a concessão dos recursos hídricos, através de bacias hidrográficas, tem papel fundamental na gestão ambiental porque a água é um indicador que se presta a modelagens de simulação. É necessário quantificar o funcionamento hidráulico, para medir a partir de bases técnicas a sua poluição e, conseqüentemente o seu bom uso, bem como suas características fisiográficas da bacia de água.

Segundo ANA (2009) a base técnica da concessionária permite acrescentar ao cenário futuro da empresa concedida, os interesses dos diversos atores envolvidos em determinada bacia. Conseqüentemente, avaliam-se quem ganha e quem perde nesses cenários. Trata-se de uma base econômica e financeira que permitirá quantificar os investimentos necessários, bem como o valor a ser cobrado, com base em seu custo e relativos lucros.

Tucci (2003) acredita que a disposição do consumidor em pagar mais pelo serviço e produto oferecidos, dispõe da garantia de gestão responsável e sustentável que se sucederá com uma concessão, principalmente. Quanto melhor a qualidade da gestão, menor o caráter impositivo da cobrança.

Já Santos (2004) diz que a importância em uma concessão está na maneira com que a negociação na fase de planejamento ocorre pelo fato dos recursos hídricos estarem ligados a várias entidades públicas e privadas. Ressalta ainda que quando o esgotamento do bem regulável atinge um patamar crítico, surgem os conflitos.

Acrescenta Tucci (2003) que por esse motivo foi instituído o Comitê de Bacias, por objetivo de promover ações integradas entres os interessados nas negociações. Para Tucci (2003) o poder público tem que assumir a responsabilidade sobre os recursos hídricos, controlar o seu uso, mas havendo possibilidade de sua gestão, pela complexidade, deve ser desfocada com intuito de permitir a inferência de diversos interessados e tornar o serviço oferecido viável.

ANA (2009) relata que a base legal, constituída pelo conjunto de leis, decretos, normas e regulamentos ligados ao uso e controle dos recursos hídricos, conforme um modelo de gerenciamento de águas adotado pelo Estado. No caso do Brasil, por exemplo, até o advento da Lei 
de Recursos Hídricos, o modelo de gestão era o do gerenciamento pelo tipo de uso da água, existindo diversos órgãos e entidades públicas com atribuições de gestão da água, de forma desarticulada e ineficiente.

\subsection{Hipótese e cenários}

Mediante esta revisão teórica sobre a teoria dos jogos e a concessão dos recursos hídricos e também, conforme o problema de pesquisa, objetivo e hipótese foram formulados os seguintes cenários:

Assumir ou conceder? Aceita ou recusa da população? O dilema em torno desse estudo se caracteriza pelos cenários possíveis, como por exemplo, o agente principal, no caso específico a prefeitura de Capivari decide por conceder ou não ao poder privado a administração dos recursos hídricos da cidade; por outro uma análise da aceitação da população para com a decisão inicial da prefeitura, em aceitar ou não, ser contra ou apoiar. Situação que pode ser visualizada pela Figura 1:

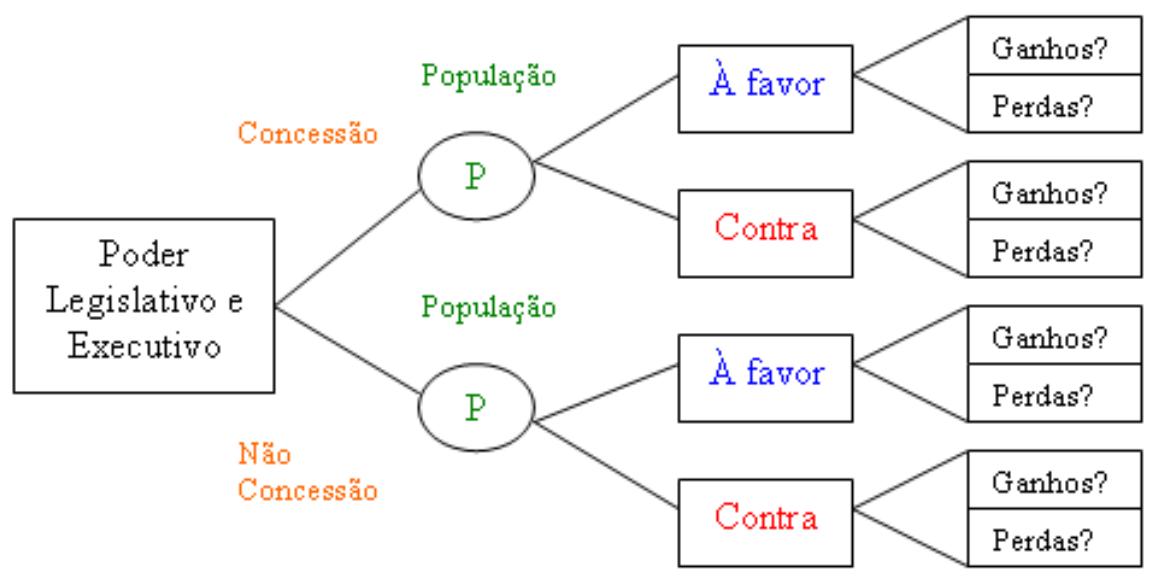

Figura 1: Cenários de Estudo

Fonte: Elaboradio peilo autor.

A concessionária deverá estabelecer no município, como empresa constituída, para fins exclusivos para a prestação do serviço público de abastecimento de água e esgotamento sanitário.

Tendo como aspecto relevante o que a população pensa sobre o processo de concessão e como reagiria diante dos cenários estabelecidos pela figura 1.1, que basicamente pode ser contra ou à favor. Para se obter um cenário favorável a população, na sua maioria, deve ser a favor da prefeitura na decisão de conceder ou não para uma empresa do setor privado os recursos hídricos disponíveis na cidade.

\section{Cenário 1: Prefeitura concede e a População é à favor}

População é a favor - os direitos emergentes da concessão poderão servir de garantia de financiamento que tenham por objetivo à melhoria do sistema de abastecimento de água e esgoto, ou em ações de desenvolvimento operacional da Concessionária.

\section{Cenário 2: Prefeitura concede e a População é contra}

População é contra - não se caracteriza como descontinuidade do serviço a sua interrupção, quando motivado por razões de ordem técnica ou de segurança, por inadimplemento do usuário, 
considerando o interesse da coletividade. Mas com uma perda substancial em termos de tempo e atraso para o desenvolvimento.

\section{Cenário 3: Prefeitura não concede e a População é a favor}

População é a favor - pode gerar mais "crédito" ao sistema público de gestão de água esgoto e melhorar a imagem do SAAE (Serviço Autônomo de Água e Esgoto) que atualmente administra os recursos disponíveis, em termos de recursos naturais, de pessoal, financeiros, verbas e outros. Pode provar conscientização de utilização e consumo perante o consumidor, visto que pode aumentar e melhorar a maneira com que a população encara o problema da falta de água.

\section{Cenário 4: Prefeitura não concede e a População é contra}

População é contra - surge como um forte candidato a pior dos cenários, pois causa a insatisfação do consumidor final, que é aquele que paga pelos serviços oferecidos, causa insatisfação e atraso para o município, ao passo que se optasse pela concessão os investimentos já seriam palpáveis e visíveis para toda a população.

\section{MÉTODO DE PESQUISA}

O presente estudo é uma pesquisa exploratória a qual de acordo com Churchill e Peter (2000) tem como enfoque a descoberta de idéias ou maior conhecimento sobre um tema ou problema específico de estudo. Ainda segundo Churchill e Peter (2000), a pesquisa exploratória é apropriada para qualquer problema do qual existe pouco conhecimento.

No caso deste estudo, a dimensão da concessão ou não dos recursos hídricos no município de Capivari é uma questão nova ainda pouco estudada que esta investigação buscou explorar. Segundo Malhotra (2001) a pesquisa exploratória fornece flexibilidade em relação ao uso de outros métodos e agrega valor no desenvolvimento de hipóteses. A pesquisa exploratória também envolve a avaliação de teorias e conceitos existentes e sua aplicação aos problemas, quando novas teorias e conceitos podem ser desenvolvidos.

Para atingir o objetivo proposto, a coleta de dados foi realizada em duas etapas: uma exploratória (qualitativa) e outra descritiva (quantitativa). As entrevistas pessoais foram realizadas no ano de 2009, no município de Capivari, conduzidas pelo próprio autor. O local das entrevistas, na maior parte das vezes, foi realizado na câmara municipal de Capivari, junto aos nove vereadores (representantes do Poder Legislativo), caracterizados aqui por entrevistados A, B, C, D, E, F, G, H e I e com o prefeito e vice-prefeito (representantes do Poder Executivo), caracterizados aqui por entrevistados X e Y. Essa etapa da pesquisa foi realizada no mês de março de 2009.

$\mathrm{Na}$ amostragem da segunda etapa foram entrevistados 100 (cem) consumidores do sistema de abastecimento de água Castelani e 100 (cem) consumidores do sistema central. Tendo uma totalidade de 200 respondentes na segunda etapa. Nessa etapa as pesquisas ocorreram no mês de outubro de 2009.

\section{APRESENTAÇÃO DOS RESULTADOS E DISCUSSÕES}

Esta seção apresenta a decisão dos consumidores quanto à concessão dos recursos hídricos; a análise de equilíbrio de Nash; os cenários de concessão com a opinião dos Poderes Executivo e Legislativo; a percepção dos consumidores; e a expectativa dos consumidores e por fim as principais contribuições da Teoria dos Jogos para administração pública.

Conforme mostra o Gráfico 1 as porcentagem são iguais para os dois sistemas, 33\% são favoráveis a concessão do SAAE e 67\% são contra. Mantendo uma similaridade entre os sistemas 
com relação a essa variável, na qual as opiniões convergem de um sistema para o outro nesse aspecto.

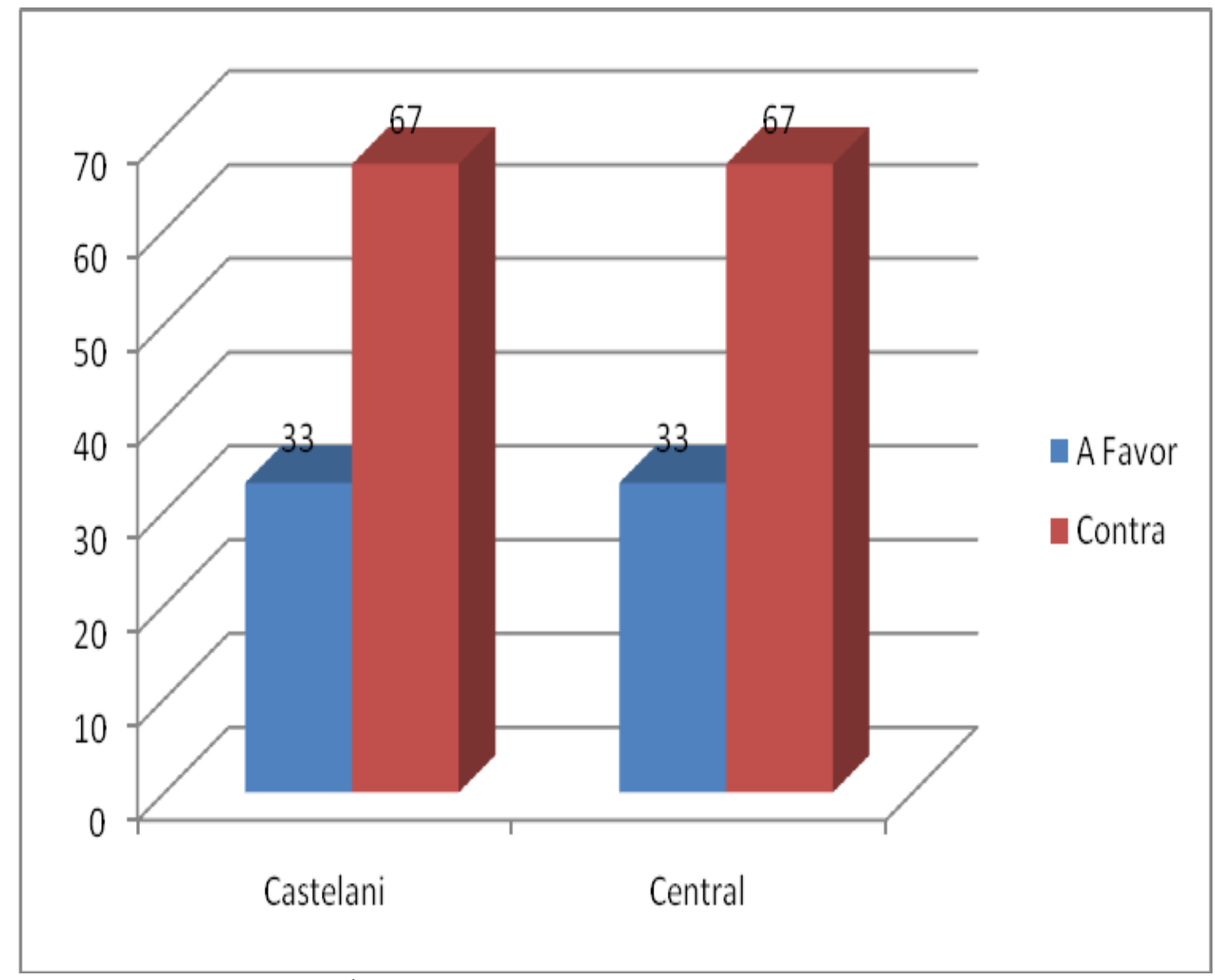

Gráfico 1: Em relação à concessão do SAAE

Fonte: Elaborado pelo autor.

Apesar da maioria dos consumidores não serem conscientes ou pouco conscientes sobre a concessão do SAAE em ambos os sistemas, a maioria dos respondentes se posicionou contra a concessão dos serviços, optando para que o próprio SAAE com recursos públicos funcione, opera e seja administrado. Isto demonstra que a população tem preferências bem definidas mesmo tendo pouca consciência do que é uma concessão, optando por favorecer o patrimônio público e a gestão própria dos recursos hídricos. 


\begin{tabular}{|c|c|c|c|c|c|c|}
\hline Esgoto & Moda & $\%$ & Média & Mínimo & Máximo & Desvio Padrão \\
\hline Preço justo da tarifa de esgoto & DT & 30 & 2,31 & 1 & 5 & 1,147 \\
\hline Um correto tratamento de esgoto & $\mathrm{C}$ & 32 & 2,73 & 1 & 5 & 1,280 \\
\hline $100 \%$ de tratamento de esgoto encanado & $\mathrm{N}$ & 25 & 2,68 & 1 & 5 & 1,296 \\
\hline \multicolumn{7}{|l|}{ Água } \\
\hline Preço justo da tarifa de água & $\mathrm{D}$ & 31 & 2,99 & 1 & 5 & 1,153 \\
\hline $100 \%$ de fornecimento de água encanada & $\mathrm{C}$ & 31 & 3,45 & 1 & 5 & 1,284 \\
\hline Cumprimento dos padrões de potabilidade (cor, odor, sabor...) & $\mathrm{N}$ & 31 & 2,95 & 1 & 5 & 1,203 \\
\hline Boa qualidade da água na rede pública & $\mathrm{C}$ & 30 & 3,21 & 1 & 5 & 1,211 \\
\hline Adicão de cloro e flúor na água é feita de maneira correta & $\mathrm{C}$ & 42 & 3,50 & 1 & 5 & 1,222 \\
\hline Imediata resolução dos problemas relacionados a água & $\mathrm{N}$ & 30 & 3,07 & 1 & 5 & 1,168 \\
\hline Total disponibilidade de água nas torneiras & $\mathrm{C}$ & 33 & 2,97 & 1 & 5 & 1,261 \\
\hline \multicolumn{7}{|l|}{ Servicos } \\
\hline Concerto de canos de água quebrados (demora do concerto, como é feito....) & $\mathrm{D}$ & 31 & 2,54 & 1 & 5 & 1,162 \\
\hline Leitura de hidrômetro & $\mathrm{D}$ & 30 & 2,91 & 1 & 5 & 1,105 \\
\hline Atendimento telefônico (reclamações, dúvidas..) & $\mathrm{N}$ & 39 & 2,92 & 1 & 5 & 1,046 \\
\hline Eficiência na qualidade dos serviços prestados & $\mathrm{N}$ & 30 & 2,84 & 1 & 5 & 1,172 \\
\hline Preço mais caro dos serviços & $\mathrm{D}$ & 49 & 2,19 & 1 & 5 & 0,997 \\
\hline Preço mais baixo dos serviços & $\mathrm{C}$ & 33 & 3,25 & 1 & 5 & 1,345 \\
\hline Agilidade e tecnologia moderna & $\mathrm{D}$ & 28 & 2,91 & 1 & 5 & 1,274 \\
\hline Troca de hidrômetros quebrados & $\mathrm{N}$ & 27 & 3,18 & 1 & 5 & 1,220 \\
\hline Redução da perda de água nas tubulações & $\mathrm{DT}$ & 30 & 2,50 & 1 & 5 & 1,324 \\
\hline O SAAE aplica medidas de redução da inadimplência & $\mathrm{N}$ & 32 & 3,26 & 1 & 5 & 1,197 \\
\hline \multicolumn{7}{|l|}{ Obras } \\
\hline Proteção do patrimônio público (mananciais, construcooes, poços artesianos e histó & $\mathrm{C}$ & 24 & 3,21 & 1 & 5 & 1,381 \\
\hline Construcãa da ETA 3 (estação de tratamento) & $\mathrm{c}$ & 35 & 3,52 & 1 & 5 & 1,163 \\
\hline Perfuração de mais poços artesianos & $\mathrm{c}$ & 41 & 3,71 & 1 & 5 & 0,983 \\
\hline Preocupação com a manutenção dos poços artesianos existentes & $\mathrm{C}$ & 45 & 3,93 & 1 & 5 & 0,972 \\
\hline
\end{tabular}

Tabela 1: Percepção Sistema de Abastecimento de Água Castelani Fonte: Dados elaborados no Software SPSS.

As escalas que vão de Discordo Totalmente (DT - 1) até Concordo Totalmente (CT - 5) tendo também como opções Discordo (D - 2), Neutro (N - 3) e Concordo (C - 4). Sendo que estão expressas as opiniões e percepções dos consumidores do sistema de abastecimento de água Castelani, visa criar um panorama atual da situação.

Na questão de obras houve uma unanimidade, com todas as maiores frequiências situadas em Concordo (C), demonstrando que a população percebe que é importante o investimento em obras como: construção da ETA 3 (35\%), proteção do patrimônio público (24\%), perfuração e manutenção de poços artesianos (41\% e $45 \%)$.

Com Discordo (D) aparecendo na maioria das vezes (4) nas variáveis referente aos serviços prestados, mostra o descontentamento dos consumidores com relação aos itens citados na Tabela 6 , como preço mais caro da tarifa de água (49\%), concerto de canos quebrados (31\%), discordam também que o SAAE tenha tecnologia e agilidade (28\%).

O Gráfico ilustra a variável preço da tarifa de esgoto, com uma freqüência de $30 \%$ para Discordo Totalmente e 30\% para Discordo, com um desvio padrão de 1,147 , que mostra a percepção do consumidor pelo custo elevado do esgoto. Isso mostra ainda que o preço da tarifa de esgoto causa discordância na opinião dos consumidores. 


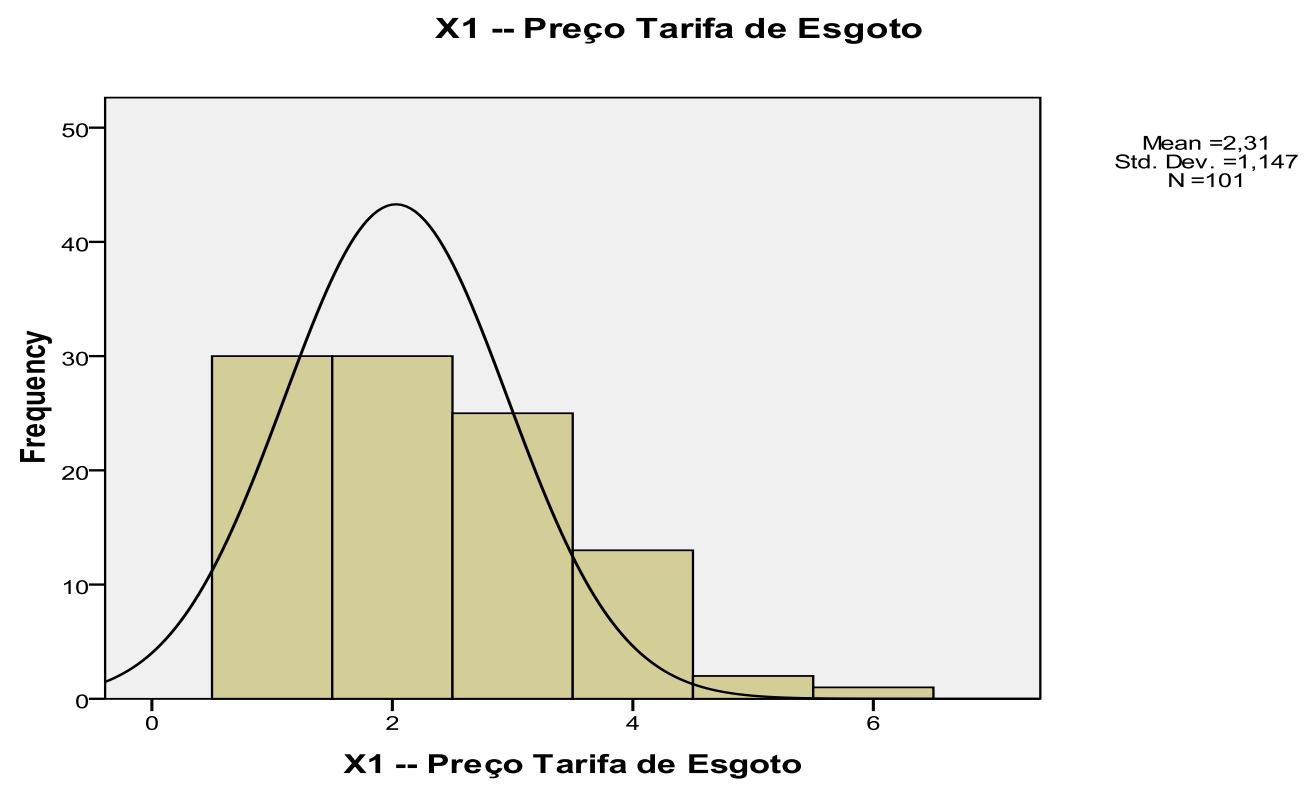

Gráfico 2: Variável: Preço da Tarifa de Esgoto

Fonte: dados da pesquisa

Os respondentes demonstram-se neutros, ou seja, tem imparcialidade sobre as variáveis: $100 \%$ de esgoto tratado (25\%), na área de esgotos; cumprimento dos padrões de potabilidade (31\%) e resolução dos problemas relacionados na área de água (30\%); na questão dos serviços são apontados quatro itens neutros: atendimento telefônico (39\%), eficiência na qualidade dos serviços prestados $(30 \%)$, troca de hidrômetros quebrados $(27 \%)$ e redução da inadimplência (32\%). O Gráfico 11 demonstra a percepção dos consumidores quanto ao preço da tarifa de esgoto.

Em se tratando da percepção dos consumidores do Sistema Central

Na parte da água a maioria dos respondentes do Sistema Central, opta por Concorda (C) ou é Neutro (N) com relação as variáveis correspondentes, não havendo nenhuma maioria pra Discordo Totalmente (DT), Discordo (D) e Concordo Totalmente (CT), mostra uma certa satisfação com relação ao assunto. Sendo a freqüência em Concordo (C) para preço da tarifa de água (33\%), 100\% de fornecimento de água encanada (46\%), adição de cloro e flúor na água (54\%), resolução dos problemas relacionados a água (31\%) e disponibilidade de água nas torneiras (40\%). 


\begin{tabular}{|c|c|c|c|c|c|c|}
\hline Esgoto & Moda & $\%$ & Média & Mínimo & Máximo & Desrio Padrà \\
\hline Preço justo da tarifa de esgoto & DT & 32 & 2,45 & 1 & 5 & 1,212 \\
\hline Um correto tratamento de esgoto & $\mathrm{C}$ & 30 & 2,98 & 1 & 5 & 1,296 \\
\hline $100 \%$ de tratamento de esgoto encanado & $\mathrm{D}$ & 35 & 2,86 & 1 & 5 & 1,183 \\
\hline \multicolumn{7}{|l|}{ Água } \\
\hline Preço justo da tarifa de água & $\mathrm{C}$ & 33 & 2,59 & 1 & 5 & 1,193 \\
\hline $100 \%$ de fornecimento de água encanada & $\mathrm{C}$ & 46 & 3,82 & 1 & 5 & 1,014 \\
\hline Cumprimento dos padrões de potabilidade (cor, odor, sabor...) & $\mathrm{N}$ & 39 & 3,28 & 1 & 5 & 0,950 \\
\hline Boa qualidade da água na rede pública & $\mathrm{N}$ & 39 & 2,91 & 1 & 5 & 1,001 \\
\hline Adicão de cloro e flíor na água é feita de maneira correta & $\mathrm{C}$ & 54 & 3,44 & 1 & 5 & 0,921 \\
\hline Imediata resolução dos problemas relacionados a água & $\mathrm{C}$ & 31 & 3,25 & 1 & 5 & 1,072 \\
\hline Total disponibilidade de água nas torneiras & $\mathrm{C}$ & 40 & 3,03 & 1 & 5 & 1,187 \\
\hline \multicolumn{7}{|l|}{ Serviços } \\
\hline Concerto de canos de água quebrados (demora do concerto, como é feito....) & $\bar{D}$ & 33 & 2,61 & 1 & 5 & 1,140 \\
\hline Leitura de hidrômetro & $\mathrm{D}$ & 33 & 2,87 & 1 & 5 & 1,083 \\
\hline Atendimento telefônico (reclamações, dúvidas..) & $\mathrm{C}$ & 34 & 3,04 & 1 & 5 & 1,131 \\
\hline Eficiência na qualidade dos servicos prestados & $\mathrm{C}$ & 36 & 2,97 & 1 & 5 & 1,014 \\
\hline Preço mais caro dos serviços & $\bar{D}$ & 51 & 2,22 & 1 & 5 & 0,890 \\
\hline Preço mais baixo dos servicos & $\mathrm{C}$ & 46 & 3,33 & 1 & 5 & 1,201 \\
\hline Agilidade e tecnologia moderna & $\mathrm{N}$ & 29 & 2,76 & 1 & 5 & 1,258 \\
\hline Troca de hidrômetros quebrados & $\mathrm{C}$ & 39 & 3,22 & 1 & 5 & 1,145 \\
\hline Redução da perda de água nas tubulações & $\mathrm{N}$ & 42 & 3,00 & 1 & 5 & 1,049 \\
\hline 0 SAAE aplica medidas de redução da inadimplência & $\mathrm{D}$ & 34 & 2,81 & 1 & 5 & 1,189 \\
\hline \multicolumn{7}{|l|}{ Obras } \\
\hline Proteção do patrimônio público (mananciais, construções, pocos artesianos e histór & $\mathrm{D}$ & 38 & 2,70 & 1 & 5 & 1,277 \\
\hline Construção da ETA 3 (estação de tratamento) & $\mathrm{C}$ & 53 & 3,84 & 1 & 5 & 0,946 \\
\hline Perfuração de mais poços artesianos & $\mathrm{C}$ & 62 & 3,77 & 1 & 5 & 0,847 \\
\hline Preocupação com a manutencão dos poços artesianos existentes & $\mathrm{C}$ & 54 & 3,79 & 1 & 5 & 0,931 \\
\hline
\end{tabular}

Tabela 2: Percepção Sistema de Abastecimento de Água Central

Fonte: Dados da pesquisa.

No Gráfico 3 está expresso a variável de obras, correspondente a construção da ETA 3. Como mostra o gráfico a maioria concorda com os investimentos que devem ser realizados nessa área. O Gráfico também apresenta um desvio padrão de 0,946 para a variável em questão. $\mathrm{O}$ baixo desvio padrão mostra que os dados variam pouco com relação a média.

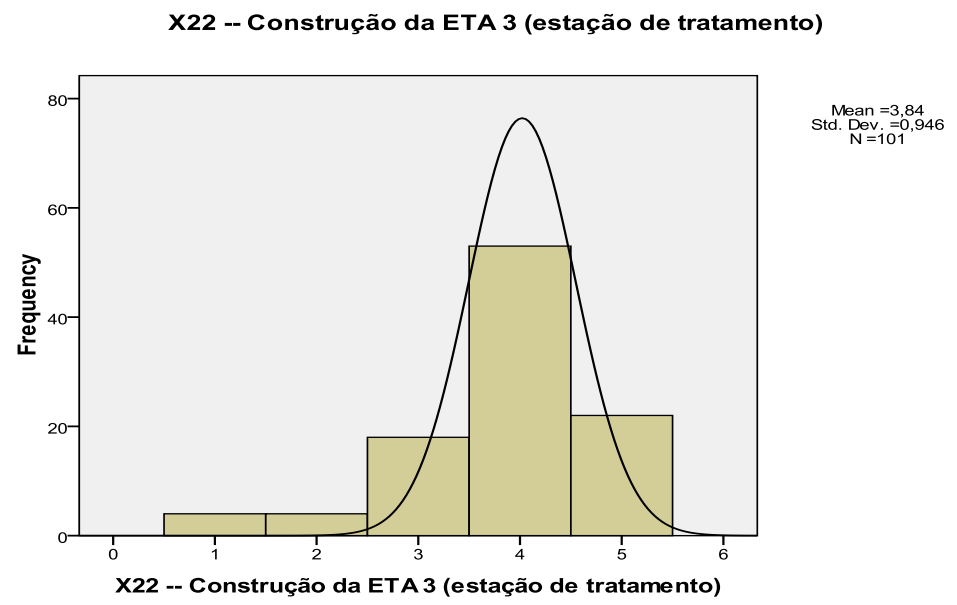

Revista de Gestão Social e Ambiental - RGSA, São Paulo, v. 5, n. 2, p. 187-210 mai./ago. 2011. 


\section{Gráfico 3: Variável: Construção da ETA 3.}

Fonte: Dados da pesquisa.

Com relação as obras quase que unanimidade entre os dos sistemas: Castelani e Central da necessidade e da importância com que o SAAE e os consumidores olham para essa questão, tanto na preservação e manutenção quanto na necessidade da obtenção de mais fontes naturais de água potável.

De modo geral pode-se afirmar que a população percebe os serviços do SAAE de forma insatisfatória, ou seja, discordam dos serviços prestados ligados a área de esgoto, e de certa forma, concorda com o oferecido com relação a água, tanto na distribuição, qualidade e preço. Enquanto os consumidores de ambos os sistemas estão preocupados com a manutenção e preservação de todo o patrimônio que envolve a água e os recursos hídricos. A seguir são descritos alguns comentários dos entrevistados do sistema Castelani:

“A água acaba depois das 7 horas da noite e quando chega, que seria já no outro dia ela vem lotada de cloro".

"Fazem ligações de água em terrenos que nem pertence a pessoa ou bem dizendo em terrenos invadidos. E em muitas das vezes para pessoas que já tem casa própria".

"A administração hoje é precária, seja herdada ou adquirida recentemente, mas sem a preocupação em manutenções preventivas e corretivas são responsáveis pelos maiores prejuízos, gastos estes que poderiam ser empregados em empreendedorismo".

"Até o momento está uma distribuição ótima e os serviços estão seguindo dentro do padrão, não sei como vai ser amanhã...".

Insatisfeitos com a administração dos serviços prestados à população até então, no que se refere à falta de preparo, tanto no atendimento, como na manutenção, conseqüentemente prevenção e preservação no desgaste de bens públicos de alta importância para a comunidade onde deveriam ser prioritários os investimentos, evitando desperdícios que geram não só insatisfação dos moradores, mas também perdas inadmissíveis para todos.

E ainda a reativação de captação de água do manancial João Láu e também do reservatório de água da Pio XII além, da modernização do sistema elétrico da estação elevatória do Caraça e da ETA II que receberam moto bombas, conjuntos de comando com programador horário, módulos tubulares de decantação, canaletas de coleta de água decantada e medidor magnético. Esses investimentos ilustram o interesse do atual Governo Municipal e sua administração na solução de muitos problemas relevantes ao fornecimento de água. A seguir são descritos alguns comentários dos entrevistados do sistema Central:

"Falta de água nos horários de pico, na hora do banho de sexta-feira e aos sábados, a água diminui e chega a acabar."

"Gostaria que a administração 'financeira' cuidasse das contas (entrada e saída), para melhorar e sobrar mais para os serviços e qualidade da água. Com o aumento da água a inadimplência vai aumentar. Se eu não consigo pagar uma conta de R \$39,80 como vou conseguir pagar uma conta de R\$ $52,13 ? "$. 
"A discordância é quando tem reparo e chega a ficar o dia todo, sem água sem avisar".

"Pedido de ligação e re-ligação de água nas casas, o serviço em Capivari demora no mínimo um mês".

O SAAE busca em suas ações um controle mais abrangente em termos de fiscalização de efluentes de indústrias, dos mananciais, do reflorestamento da mata ciliar que desempenha múltiplas funções nas margens do rio, pois é sua proteção física, desempenhando papel de corredor genético para a flora e fauna e, que tem relação direta com a qualidade da água seria um passo muito importante para alcançar a necessária recuperação e preservação. Em se tratando das expectativas quanto a Concessão no Sistema Castelani

Nas variáveis que correspondem ao esgoto a maior freqüência está situada no Discordo (D) com $38 \%$ no preço da tarifa de esgoto, $28 \%$ tratamento de esgoto e $31 \%$ na necessidade de se trata $100 \%$ de esgoto encanado.

\begin{tabular}{|c|c|c|c|c|c|c|}
\hline Esgoto & Moda & $\%$ & Média & Mínimo & Máximo & Desrio Padrão \\
\hline Preço justo da tarifa de esgoto & $\mathrm{D}$ & 38 & 2,22 & 1 & 5 & 1,188 \\
\hline Um correto tratamento de esgoto & $\mathrm{D}$ & 28 & 3,13 & 1 & 5 & 1,347 \\
\hline $100 \%$ de tratamento de esgoto encanado & $\mathrm{D}$ & 31 & 3,17 & 1 & 5 & 1,342 \\
\hline \multicolumn{7}{|l|}{ Água } \\
\hline Preço justo da tarifa de água & $\mathrm{D}$ & 32 & 2,62 & 1 & 5 & 1,121 \\
\hline $100 \%$ de formecimento de água encanada & $\mathrm{C}$ & 28 & 3,28 & 1 & 5 & 1,242 \\
\hline Cumprimento dos padrões de potabilidade (cor, odor, sabor...) & $\mathrm{C}$ & 32 & 3,26 & 1 & 5 & 1,197 \\
\hline Boa qualidade da água na rede pública & $\mathrm{C}$ & 36 & 3,21 & 1 & 5 & 1,211 \\
\hline Adição de cloro e flúor na água é feita de maneira correta & $\mathrm{N}$ & 30 & 3,21 & 1 & 5 & 1,203 \\
\hline Imediata resolução dos problemas relacionados a água & $\mathrm{D}$ & 28 & 3,10 & 1 & 5 & 1,323 \\
\hline Total disponibilidade de água nas tomeiras & $\mathrm{C}$ & 31 & 3,21 & 1 & 5 & 1,283 \\
\hline \multicolumn{7}{|l|}{ Serviços } \\
\hline Concerto de canos de água quebrados (demora do concerto, como é feito....) & $\mathrm{D}$ & 32 & 2,94 & 1 & 5 & 1,215 \\
\hline Leitura de hidrômetro & $\mathrm{C}$ & 30 & 3,15 & 1 & 5 & 1,228 \\
\hline Atendimento telefônico (reclamações, dúvidas..) & $\mathrm{N}$ & 32 & 2,77 & 1 & 5 & 1,165 \\
\hline Eficiência na qualidade dos serviços prestados & $\mathrm{D}$ & 30 & 3,02 & 1 & 5 & 1,208 \\
\hline Preço mais caro dos serviços & DT & 32 & 2,42 & 1 & 5 & 1,314 \\
\hline Preço mais baixo dos serviços & $\mathrm{C}$ & 40 & 3,57 & 1 & 5 & 1,071 \\
\hline Agilidade e tecnologia moderna & $\mathrm{C}$ & 42 & 3,54 & 1 & 5 & 1,091 \\
\hline Troca de hidrômetros quebrados & $\mathrm{C}$ & 32 & 3,24 & 1 & 5 & 1,387 \\
\hline Redução da perda de água nas tubulações & $\mathrm{D}$ & 32 & 3,24 & 1 & 5 & 1,297 \\
\hline OSAAE aplica medidas de redução da inadimplência & $\mathrm{C}$ & 30 & 3,33 & 1 & 5 & 1,234 \\
\hline \multicolumn{7}{|l|}{ Obras } \\
\hline Proteção do patrimônio público (mananciais, construções, poços artesianos e história. & $\mathrm{C}$ & 30 & 3,15 & 1 & 5 & 1,381 \\
\hline Construção da ETA 3 (estação de tratamento) & $\mathrm{C}$ & 28 & 3,20 & 1 & 5 & 1,379 \\
\hline Perfuração de mais poços artesianos & $\mathrm{C}$ & 32 & 3,30 & 1 & 5 & 1,205 \\
\hline Preocupação com a manutenção dos poços artesianos existentes & $\mathrm{C}$ & 30 & 3,34 & 1 & 5 & 1,275 \\
\hline
\end{tabular}

Tabela 3: Expectativa quanto a Concessão no Sistema Castelani

Fonte: Dados elaborados no Software SPSS.

Já na variável água aparece quatro Concordo (C) como freqüência mais repetida, sendo $28 \%$ em total de fornecimento de água encanada, 32\% cumprimento dos padrões de potabilidade, $36 \%$ qualidade da água na rede pública e $31 \%$ de disponibilidade de água nas torneiras. 
Nos serviços aparece um Discordo Totalmente (DT) como maioria, na parte do preço mais caro dos serviços $(32 \%)$. E em todo o resultado não aparecendo nenhuma freqüência maior como Concordo Totalmente (CT), mostram-se mais uma vez o descontentamento, com os serviços, e também não concordam com a concessão do mesmo.

Nas variáveis de obras, novamente uma maioria Concorda (C) que a possível concessionária deve preservar o patrimônio e os poços artesianos, assim como acreditam que o SAAE hoje também o faz e deve continuar fazendo.

No Gráfico 4 com a variável: cumprimento dos padrões de potabilidade averigua-se que os consumidores do sistema Castelani esperam de uma possível concessão um cumprimento dessa variável entre Neutro e Concordo. Essa variável apresenta desvio padrão de 1,197.

\section{X6 -- Cumprimento dos padrões de potabilidade (cor, odor, sabor...)}

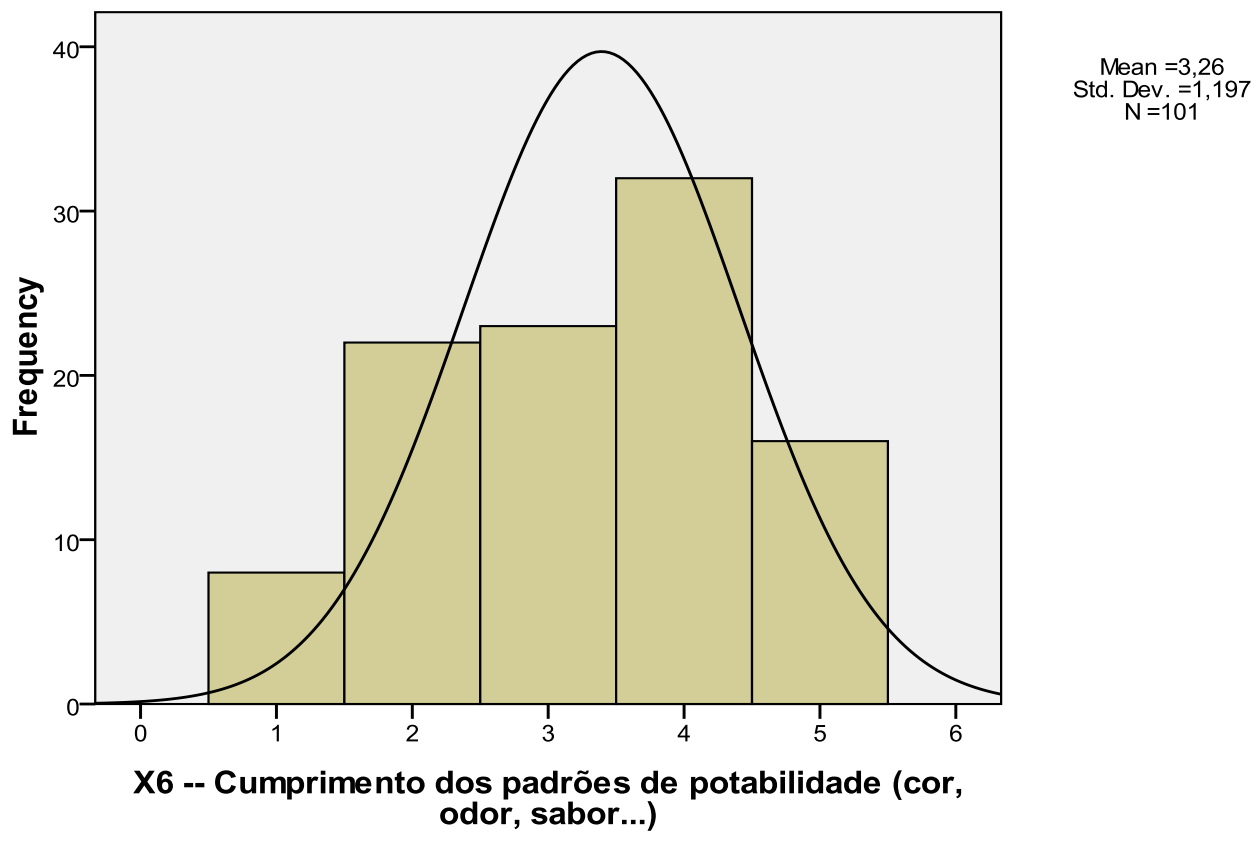

Gráfico 4: Variável: Cumprimento dos padrões de potabilidade

Fonte: dados da pesquisa

$\mathrm{Na}$ expectativa quanto a Concessão no Sistema Central, a variável esgoto obtiveram-se as seguintes freqüências: para Discordo (D), preço da tarifa de esgotos (35\%) e $100 \%$ de esgoto tratado encanado (34\%). E apenas uma variável com Concordo (C), tratamento de esgoto (37\%).

Já a variável água teve apenas como Concordo (C), adição de cloro e flúor $(41 \%)$ e disponibilidade de água nas torneiras (33\%). E parte do Discordo (D) questões como: preço da tarifa de água (30\%), 100\% de fornecimento de água encanada (27\%), cumprimento dos padrões de potabilidade $(37 \%)$, qualidade da água na rede pública $(36 \%)$ e resolução dos problemas relacionados a água $(30 \%)$.

A parte de serviços reflete o equilíbrio nas opiniões com cinco vezes aparecendo Discordo (D): concerto de canos de água quebrado, leitura de hidrômetro, atendimento telefônico, preço mais caro dos serviços e redução da perda de água nas tubulações. E cinco vezes o Concordo (C): eficiência na qualidade dos serviços prestados, preço mais baixo dos serviços, agilidade e tecnologia moderna, troca de hidrômetros quebrados e redução da inadimplência. 
Para as obras novamente a alternativa Concordo (C) predomina sobre as outras com percentuais de $26 \%, 37 \%, 41 \%$ e $39 \%$, para proteção do patrimônio, construção da ETA 3, perfuração e manutenção de poços artesianos, respectivamente.

O descontentamento da população com relação à percepção sobre os serviços atuais, não reflete o favorecimento da concessão do SAAE. Torna o consumidor mais exigente e preocupado com relação ao futuro da autarquia.

\begin{tabular}{|c|c|c|c|c|c|c|}
\hline Esgoto & Moda & $\%$ & Média & Mínimo & Máximo & Desrio Padrà 0 \\
\hline Preço justo da tarifa de esgoto & $\bar{D}$ & 35 & 2,46 & 1 & 5 & 1,127 \\
\hline Um correto tratamento de esgoto & $\mathrm{C}$ & 37 & 2,91 & 1 & 5 & 1,192 \\
\hline $100 \%$ de tratamento de esgoto encanado & $\mathrm{D}$ & 34 & 2,85 & 1 & 5 & 1,203 \\
\hline \multicolumn{7}{|l|}{ Água } \\
\hline Preço justo da tarifa de água & $\mathrm{D}$ & 30 & 2,59 & 1 & 5 & 1,234 \\
\hline $100 \%$ de fornecimento de água encanada & $\mathrm{D}$ & 27 & 3,05 & 1 & 5 & 1,359 \\
\hline Cumprimento dos padrões de potabilidade (cor, odor, sabor...) & $\mathrm{D}$ & 37 & 2,99 & 1 & 5 & 1,204 \\
\hline Boa qualidade da água na rede pública & $\mathrm{D}$ & 36 & 3,06 & 1 & 5 & 1,231 \\
\hline Adição de cloro e flúor na água é feita de maneira correta & $\mathrm{C}$ & 41 & 3,24 & 1 & 5 & 1,159 \\
\hline Imediata resolução dos problemas relacionados a água & $\mathrm{D}$ & 30 & 2,96 & 1 & 5 & 1,224 \\
\hline Total disponibilidade de água nas torneiras & $\mathrm{D}$ & 32 & 2,88 & 1 & 5 & 1,314 \\
\hline \multicolumn{7}{|l|}{ Serviços } \\
\hline Concerto de canos de água quebrados (demora do concerto, como é feito....) & $\mathrm{C}$ & 31 & 2,76 & 1 & 5 & 1,242 \\
\hline Leitura de hidrômetro & $\mathrm{D}$ & 25 & 2,96 & 1 & 5 & 1,235 \\
\hline Atendimento telefônico (reclamações, dúvidas..) & $\mathrm{D}$ & 34 & 2,93 & 1 & 5 & 1,000 \\
\hline Eficiência na qualidade dos serviços prestados & $\mathrm{D}$ & 39 & 2,68 & 1 & 5 & 1,264 \\
\hline Preço mais caro dos servicos & $\mathrm{C}$ & 29 & 2,85 & 1 & 5 & 1,144 \\
\hline Preço mais baixo dos servicos & $\mathrm{D}$ & 41 & 2,02 & 1 & 5 & 1,000 \\
\hline Agilidade e tecnologia moderna & $\mathrm{C}$ & 41 & 3,55 & 1 & 5 & 5,935 \\
\hline Troca de hidrômetros quebrados & $\mathrm{C}$ & 31 & 3,12 & 1 & 5 & 1,395 \\
\hline Redução da perda de água nas tubulações & $\mathrm{C}$ & 30 & 3,01 & 1 & 5 & 1,367 \\
\hline O SAAE aplica medidas de redução da inadimplência & $\mathrm{C}$ & 26 & 2,97 & 1 & 5 & 1,261 \\
\hline \multicolumn{7}{|l|}{ Obras } \\
\hline Proteção do patrimônio público (mananciais, construções, poços artesianos e histór & $\mathrm{C}$ & 26 & 2,96 & 1 & 5 & 1,363 \\
\hline Construção da ETA 3 (estação de tratamento) & $\mathrm{C}$ & 37 & 3,23 & 1 & 5 & 1,318 \\
\hline Perfuração de mais poços artesianos & $\mathrm{C}$ & 41 & 3,46 & 1 & 5 & 1,253 \\
\hline Preocupação com a manutenção dos poços artesianos existentes & $\mathrm{C}$ & 39 & 3,35 & 1 & 5 & 1,307 \\
\hline
\end{tabular}

Tabela 4: Expectativa quanto a Concessão no Sistema Central Fonte: Dados elaborados no Software SPSS.

De modo geral pode-se afirmar que a população espera de um serviço de água é muito além do que lhes é oferecido e disponível no momento. Não refletindo no caso da concessão a opinião dos consumidores por um sistema ter mais consistência ou apresentar melhor qualidade nos serviços de água e esgoto do que o outro, fazendo os dois sistemas discordarem da concessão do SAAE.

Como mostra o gráfico 5, na variável redução de perda de água nas tubulações, a expectativa do consumidor no sistema Central continua a mesma do que na percepção do que o SAAE já oferece, não mudando em nada seu conceito sobre o aspecto. $\mathrm{O}$ desvio padrão na redução da perda de água é de 1,415 . 
X19 -- Redução da perda de água nas tubulações

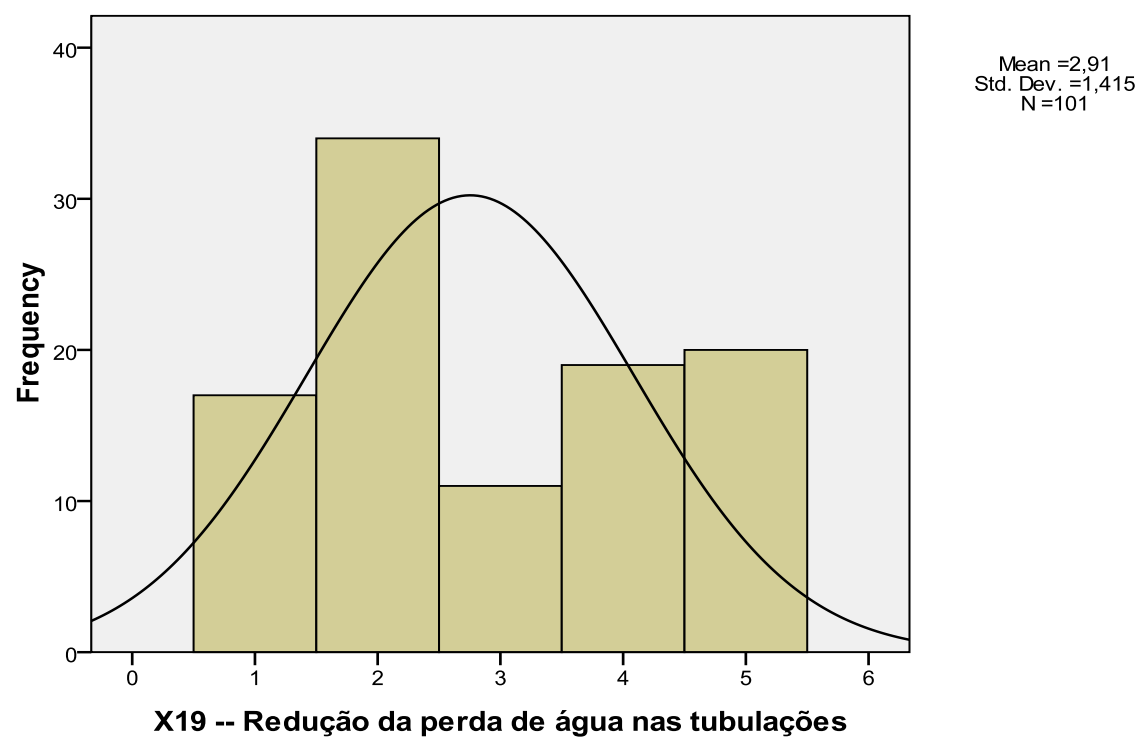

Gráfico 5: Variável: Redução de perda de água nas tubulações

Fonte: Gerado através do Software SPSS.

Segue alguns comentários obtidos sobre a expectativa de uma concessão do SAAE, no qual os respondentes puderam descrever alguma consideração que tiveram sobre o sistema de abastecimento e os serviços do SAAE. "Espero que a empresa coloque uma pessoa de moto pela cidade para fiscalizar o desperdício de água nas casas".

A insatisfação gerada por moradores descontentes com uma fiscalização menos elaborada aumenta na proporção em que moradores mesmo com dificuldades pagam suas contas em dia e acabam por terem que dividir um consumo ainda escasso.

"Espero que a nova concessionária possa fazer o que eles ainda (SAAE) tentam fazer e não conseguem".

"Com a concessão espero melhoras no atendimento, nos esgotos, pois quando eles entopem o encanamento do banheiro vira um esculacho".

Este incômodo da falta de água em horários de maior consumo tende a se estabilizar pelos investimentos que vêem sendo realizados desde o começo de 2009, pelo Governo Municipal, para sanar o incômodo da falta de água em Capivari. Entretanto, o Poder Público ainda não conseguiu sanar o problema na sua totalidade, devido a descentralização dos sistemas de abastecimento.

A percepção fica por conta de como a população, na posição de consumidores de água, avaliam o sistema de abastecimento atualmente. Já a expectativa é que a concessão do SAAE realize para os sistemas de abastecimento.

Os resultados apresentados a seguir expressam a opinião dos nove vereadores, que compõe o Poder Legislativo Capivari, e do prefeito e vice-prefeito, que compõem o Poder Executivo. 


\section{Cenário 1: Concessão e População é a favor}

Os ganhos apresentados foram que a concessão seria uma alternativa, na busca de recursos, para melhorar os serviços oferecidos pela autarquia. Também pode trazer economia em outras áreas públicas. "Eficiência na qualidade dos serviços prestados, agilidade e tecnologia
moderna. Investimentos muito caros para a esfera pública programar
sozinha". (Entrevistado A)

"São melhorias dos serviços prestados, visto que a população e os poderes Legislativo e Executivo sendo a favor, significa que os serviços públicos prestados, não estão sendo executados com êxito. Sendo assim os dois lados ganha com isso". (Entrevistado B)

"Num momento em que Capivari necessita urgentemente reformar sua administração pública, para torná-la mais eficiente e de melhor qualidade, o serviço público municipal torna-se mais ineficiente e, neste cenário, o prefeito re-envia para a câmara a privatização via concessão de serviços públicos essenciais, como lixo, água e saneamento (SAAE) e zona azul”. (Entrevistado Y)

"Sem atermos à saúde pública, educação, conservação das vias públicas entre outras, que sabemos também existir ineficiência, vamos dar ênfase aos serviços de coleta do lixo e aos prestados pelo SAAE". (Entrevistado $\mathrm{H}$ )

Para os entrevistados é necessário que haja maior racionalização e controle no Setor Público, estabelecendo metas concretas, redefinindo suas funções, reajustando seus processos, monitorando seus resultados, enfim, implementando o gerenciamento e controle:

"Se o poder público conceder a concessão e as empresas que ganharem a concessão, não prestarem os serviços contratados e os custos desses serviços prestados afetarem os cofres públicos, sendo assim quem paga por isso é a população". (Entrevistado G)

"Enquanto muitos municípios vizinhos passam por verdadeira revolução, Capivari atravessa por oito anos alheio a esse processo. Caminhou até em sentido contrário, sobre o PIB. Se as empresas privadas de Capivari buscam eficiência, eficácia e aprimoramento nas suas técnicas de gestão o mesmo não se pode dizer em relação à administração pública, que representa um retrocesso". (Entrevistado X).

\section{Cenário 2: Concessão e População é contra}

Toda concessão pública segue uma lei. Para se fazer a concessão da água, existem várias etapas que são necessárias, uma é audiência pública e deve ser realizada, para que a população possa entender e aceitar ou não o plano concessionário. Para esse cenário os Ganhos apresentados foram:

"Se o poder executivo e Legislativo conceder a concessão dos bens públicos e isso trazer melhor demanda de atendimento e benefícios sem que isso tenha mais custos para a população". (Entrevistado Y)

Para os entrevistados, a situação do SAAE precisa ser reestruturada, pois se não houver consciência disso, quem sofrerá serão os próprios munícipes, consumidores da água. O poder público deve oferecer soluções, como combater a defasagem do sistema de abastecimento e enxugar a máquina administrativa. Destacam as perdas desse processo: 
"Aumento de tarifas e perda do foco econômico para o qual o poder público foi eleito, ou seja, administrar os bens e serviços públicos". (Entrevistado I)

\section{Cenário 3: Não Concessão e População é a favor}

Para o cenário 3 foram apresentados os seguintes Ganhos:

"O poder público tem o dever de administrar com excelência aquilo que é de sua competência, e a sociedade terá: ganhos em preços menores dos serviços e o patrimônio sobre controle do governante e conseqüentemente a população". (Entrevistado X)

"Se o poder Legislativo e Executivo, se posicionar em não optar pela concessão e a população e a favor, o ganho para os poderes seria em investir em melhorias nos serviços públicos, que estão passando por dificuldades. Só assim a população optaria pela não concessão". (Entrevistado Y)

"Faz parte dos nossos objetivos criar condições que propiciem a evolução sócio-ambiental do Ser Humano; conviver em harmonia com os colaboradores, com a comunidade e com a Natureza; ter atitudes responsáveis e racionais que garantam a sustentabilidade da gestão pública $e$ desenvolver mecanismos de gestão integrada que garantam a melhoria contínua do SAAE Capivari”. (Entrevistado B)

"Um convênio de cooperação seria muito interessante na elaboração de um plano Diretor, pois assim aproveitaríamos a experiência adquirida de outros municípios, transmitindo-a para Capivari. Daremos continuidade às negociações, sempre no sentido de firmar parcerias e convênios a custo zero ou com o menor custo possivel à Prefeitura". (Entrevistado A)

Este cenário seria o possível Equilíbrio de Nash identificado através da pesquisa, sendo o que mais traria benefícios e ganhos, tanto a população quanto ao Poder Público. Pois a população demonstra ser contra a concessão dos serviços e os poderes: Executivo e Legislativo indiferentes à opinião da população quanto a isso.

Para as possíveis Perdas:

"Administração ruim levaria ao sucateamento e atraso tecnológico dos equipamentos, morosidade no atendimento custo do excesso de pessoas". (Entrevistado E)

"A perda seria mesmo sabendo que a população é favorável a concessão os poderes não investirem em melhorias nos setores públicos que estão passando por dificuldades". (Entrevistado F)

"A falta de investimentos atinge principalmente as Estações de Tratamento de Água e Esgoto. O relatório revela que há muito tempo as ETAs não passavam por manutenção. Já as ETEs dos bairros Jardim Elisa e Castelani estão com prazos de conclusão comprometidos". (Entrevistado G)

"Hoje temos funcionamento apenas as ETEs do Engenho Velho e do São João Batista. Identificamos um grave problema na ETE Engenho Velho, que estava operando apenas 20\%. da sua capacidade. Após grande esforço de nossa equipe de profissionais, em março elevamos esse percentual para os 
atuais $80 \%$, sendo que os $20 \%$ restantes serão alcançados já no próximo mês de junho". (Entrevistado Y)

"Sei que a situação do SAAE é muito grave. Posso dizer que ele está na UTI. Mas sei também que podemos resolver essa situação. E esta solução vai demorar de acordo com os caminhos que trilharmos e das parcerias que conseguiremos firmar, por isso que com toda humildade estamos pedindo ajuda". (Entrevistado X)

A água que é consumida em todos os lares atendidos pelo SAAE (Serviço Autônomo de Água e Esgoto) é captada de mananciais e poços artesianos, passando por um rígido processo de tratamento e controle sanitário antes de chegar às residências. Este tratamento deve ser feito com ajuda de tecnologia que o SAAE tem que possuir para zelar pela saúde de todo e qualquer cidadão de Capivari, mantendo esses princípios.

\section{Cenário 4: Não Concessão e População é contra}

Os Ganhos identificados no Cenário 4 foram os seguintes:

“a) preços de tarifas inferiores, b) culturalmente proteção do patrimônio público sob administração local, c) melhorias na eficiência dos serviços com investimentos". (Entrevistado B)

"É a possibilidade de economia visto que uma concessão corre se o risco de não dar certo não havendo necessidade de concessão isso significa que os poderes públicos estão trabalhando com êxito". (Entrevistado C)

"Um plano pode ser concretizado através de medidas de resultados comprovados na economia de água nos usos domésticos, industriais, comerciais, agrícolas e em outros, como por exemplo: redução de perdas em sistemas de abastecimento, manutenção de aqüíferos (como é o caso da represa Borba), despoluição de massas hídricas, aplicação de novos sistemas tarifários, caso necessário e campanhas de educação e de informação. Sabemos que este plano de trabalho é possível, mas, de execução difícil, e contará muito com uma mudança fundamental de atitude por parte da população na forma como a água é utilizada, gerida e valorizada. Trata-se, afinal, da criação de uma nova cultura da água". (Entrevistado H)

A intenção maior entre todos os moradores é de que possa haver uma boa administração, a fim de darem um passo adiante numa questão primordial e de infinita necessidade para o bem estar de toda a população.

Já as Perdas nesse cenário foram:

"Atraso tecnológico, sucateamento dos bens, deficiência na prestação dos serviços, obtemperação por parte da população sobre as reais funções do poder público (prestar serviço de qualidade)". (Entrevistado A)

"A possibilidade de que a concessão dos serviços públicos traria melhor atendimento e economia, com possibilidade de melhorar ainda mais para população". (Entrevistado C)

"O SAAE não foi administrado profissionalmente, isto é, não existia uma estrutura empresarial, com planejamento financeiro e controles de áreas vitais, como contas a receber, inadimplência, recebimentos de mercadorias, consumos de insumos químicos, energia elétrica, leituras, entrega de água 
pelo caminhão pipa, serviços de limpa fossa e consistência entre o número de hidrômetros lidos e o de aparelhos existentes". (Entrevistado E)

"Devido à falta de investimentos em segurança, os poços artesianos tornaram-se alvos fáceis para o roubo de fios e equipamentos, gerando prejuizos e comprometendo o abastecimento. Os reservatórios dos bairros Cancian e Porto Alegre estão comprometidos pela ferrugem e há o agravamento da falta de equipamentos reservas para casos de pane". (Entrevistado X)

Medidas nem sempre são bem aceitas por alguns moradores que discordam de projetos de concessões com municípios vizinhos. Há um compromisso previsto entre os 15 municípios por onde passa o rio Capivari até onde deságua, na cidade de Tietê e seus afluentes, nesta Carta de Intenções, estarão o de despoluição e limpeza do rio, tratamento de $100 \%$ de esgoto até 2012 entre outros.

\section{CONSIDERAÇÕES FINAIS}

A partir da revisão teórica é possível formular a seguinte hipótese de pesquisa: (H1) o Equilíbrio de Nash ocorre com o aceite e cooperação da população para a decisão final da prefeitura. Para haver o equilíbrio de Nash nesse jogo envolvendo a Prefeitura (Poder Executivo), a Câmara (vereadores) e a População (consumidores) é preciso primeiramente haver uma percepção positiva, um conforto e conformidade entre as partes na decisão a ser tomada. Para que o Equilíbrio de Nash possa se manter estável e todos os jogadores ganhem com isso, deve haver aceitação e, principalmente, a disponibilidade e condição de se realizar tal feito, onde a concessão ou não dos recursos hídricos está sendo levada em consideração. Aqui o fator utilidade da escolha, descrito por Nash (1950) em seu equilíbrio é considerado por todos os envolvidos no jogo.

Sobre a pergunta problema de pesquisa: se a população for à favor as decisões que prefeitura do município de Capivari adotar, será suficiente para haver equilíbrio de Nash? Pode-se afirmar que não será suficiente para haver o equilíbrio, primeiramente porque o Poder Público demonstra não se importar com a opinião da população sobre o assunto; segundo porque a população é contra a concessão e discorda com os serviços oferecidos pelo SAAE atualmente, em sua percepção.

Com relação ao objetivo: analisar conforme os cenários elaborados, o comportamento dos consumidores e a decisão do poder Executivo quanto à concessão dos recursos hídricos no município de Capivari. Os consumidores demonstram-se contra a concessão e o poder Executivo não leva isso em consideração, mas também é contra por maioria política no poder Legislativo para não aprovação do projeto de concessão do SAAE.

Para os entrevistados a concessão do SAAE não significa que o poder público deve ignorar questões como: a situação financeira, atual e perspectivas para os próximos quatro anos; a capacidade instalada para fins de captação, tratamento, armazenamento e distribuição de água, comparada à necessidade atual e futura do município de Capivari; a capacidade de tratamento de esgotos atual e perspectivas para atingir o índice de $100 \%$ de tratamento; a eficiência e eficácia de desempenho, tanto em fornecimento de água como em tratamento de esgotos, comparadas às autarquias da mesma natureza em nível regional; e a adequação do quadro de pessoal da autarquia, quanto ao nível de capacitação e adequação ao perfil técnico exigido pelo cargo, assim como adequação ao número mínimo de profissionais necessários para que o SAAE cumpra suas finalidades, sem onerar os munícipes capivarianos.

As limitações desse estudo ocorrem devido ao escopo municipal. O estudo também limita-se a alguns bairros da cidade, devido ao número de munícipes entrevistados na pesquisa de campo, não sendo a sua totalidade.

Revista de Gestão Social e Ambiental - RGSA, São Paulo, v. 5, n. 2, p. 187-210 mai./ago. 2011. 
Por outro lado, o resultado pode ser influenciado pela formação de coalizões e acordos, até o ponto de reduzir o jogo com "n" participantes. Na esfera da administração pública, podem ocorrer situações desse tipo, quando algumas organizações públicas fazem "acordos" com a iniciativa privada com a finalidade de reduzir custos e responsabilidades para focar no que realmente é essencial para o negócio da gestão pública.

Dessa forma, a Teoria dos Jogos é utilizada para a compreensão de como a administração pública evolui e opera, e de como os administradores deveriam pensar sobre as decisões estratégicas, entre elas as ambientais. Por exemplo, nessa teoria analisa-se o que ocorre quando a administração pública centraliza os setores e tarefas, como determina preço dos serviços e como os ajusta ao longo do tempo, de tal maneira pela qual a gestão pública elabora movimentos estratégicos que lhes dão vantagem e incentivos maiores.

A Teoria fornece o conhecimento organizado, desenhado para ser eficientemente transmitido e convertido em valores culturais, ambientais ou monetários. Com base nisso pode-se afirmar que: a Teoria dos Jogos permite uma análise científica para formulação de Decisões Estratégicas; a Teoria dos Jogos é a lógica da solução de conflitos na concessão dos serviços; a disputa pelo mercado é um jogo estratégico, do qual o setor público não está isento; a Teoria dos Jogos permite formular a melhor estratégia da empresa num cenário de conflito, resultante da interação ou competição entre concorrentes fortes; o conflito surge nos mercados onde a administração pública tem participação importante, seja nos mercados local, regional, ou nacional.

No cenário das concessões ocorrem os Jogos Cooperativos, quando seus participantes podem negociar contratos vinculativos de cumprimento obrigatório entre si, permitindo que realizem o planejamento de estratégias em conjunto.

Como as instituições privadas levam em conta as estratégias de seus concorrentes no Equilíbrio de Nash, espera-se que o lucro resultante para cada empresa seja mais alto do que seria num mercado completamente competitivo ou administrador pelo poder público.

Durante o processo de tomada de decisão sobre o preço ou tarifa a ser cobrado, as empresas estão praticando um jogo não cooperativo, onde cada uma estará fazendo o melhor que pode para si, levando em consideração as estratégias de sua concorrente. Porém, obtenção de um resultado cooperativo é difícil, pois os fatores mencionados estão sujeitos a mudanças no longo prazo.

Com essa pesquisa leva-se em consideração a opinião dos jogadores envolvidos Poder Executivo, Legislativo, e consumidores dos sistemas de abastecimento de água Castelani e Central. Leva-se em consideração suas percepção de como estão as variáveis esgoto, água, serviço e obras num panorama atual do SAAE e quais são suas expectativas por uma possível concessão da autarquia, utilizando-se as mesmas variáveis para percepção e expectativa.

A pesquisa deixa claro que o Poder Legislativo não considera como relevante a opinião de contra ou à favor da população com relação a concessão do SAAE. E sim, formas políticas de se governar, envolvendo muita influência partidária na decisão. Não se aplica a lógica de escolhas a partir do outro jogador.

Já os consumidores de ambos os sistemas, Castelani e Central, se posicionam contra a concessão dos serviços, formando o primeiro Equilíbrio de Nash. O Poder Público também é contra, não pela população como dito acima, mas por ideais políticos.

Por outro lado, através de dados e informações obtidos nas pesquisas de opinião dos consumidores, no fator expectativa do SAAE, houve um índice de discordância com os serviços, o esgoto a água, caracteriza assim o segundo ponto no Equilíbrio de Nash, os jogadores (população) também não estão satisfeitos com o cenário atual em que a autarquia se encontra na prestação de seus serviços e em seu funcionamento.

O terceiro ponto para se alcançar o Equilíbrio de Nash ainda não foi atingido, que será quando os Poderes Públicos descartarem a possibilidade da concessão do SAAE, assumirem de vez os serviços de água, esgoto e obras. Neste estágio, forma-se a necessidade do estabelecimento de padrões e metas a serem atingidos pelo SAAE, para que a população perceba os serviços de forma

Revista de Gestão Social e Ambiental - RGSA, São Paulo, v. 5, n. 2, p. 187-210 mai./ago. 2011. 
positiva, sem gerar ônus ou prejuízos ao sistema, para que o jogador, Poder Público, também ganhe com isso. Forma-se assim o Equilíbrio de Nash.

Por fim, a Teoria dos Jogos ajuda a entender teoricamente o processo de decisão de agentes que interagem entre si, a partir de uma compreensão da lógica da situação em que estão envolvidos. Ainda ajuda na capacidade de raciocinar estrategicamente "explorando" as possibilidades de interação dos agentes, possibilidades que nem sempre refletem a intuição humana.

\section{REFERÊNCIAS}

ANA, Agência Nacional da Água. Extraído via <http//:www.ana.gov.br>, em 24 de abril de 2009.

AUMANN, R. J. e MACHAEL, M. The Bargaining Set for Cooperative Games. Princeton: Princeton University Press, p. 443-476, 1964.

CARNEIRO, P. P. Cooperativismo: o princípio e a força existencial - social do trabalho. Belo Horizonte: Fundec, 1981.

CHURCHILL, Gilbert A. \& PETER, J. Paul. Marketing Criando Valor para os clientes. $2^{\mathrm{a}}$ Edição. São Paulo-SP: Saraiva, 2000.

CRITSINELIS, M. F. A Concessão de Serviços Públicos. São Paulo: Aérica Jurídica Edi, 2003.

DAEE, Departamento Estadual de Águas e Energia Elétrica. Extraído via <http//:www.daee.sp.gov.br>, em 23 de abril de 2009.

DANIELS, Patrícia S. Atlas da História do Mundo. 1ª Edição. São Paulo-SP: Abril, 2004.

DAY, George S \& REIBSTEIN, Davids. A Dinâmica da Estratégia Competitiva. $1^{\text {a }}$ Edição. São Paulo-SP:Campus, 1997.

DOWBOR, L.; TAGNIN R. A. Administrando a água como se fosse importante. São Paul-SP: Senac, 2005.

FIANI, Ronaldo. Teoria dos Jogos - Com Aplicação em Economia, Administração e Ciências Sociais. $2^{a}$ Edição. São Paulo-SP: Campus, 2006.

GARRIDO, R. Considerações sobre a formação de preços para a cobrança pelo uso da água no Brasil. São Paulo-SP: Igual, 2000.

JUNQUEIRA, L. P. Descentralização, intersetorialidade e rede na gestão da cidade Organizações \& Sociedade. V. 11, edição especial, p. 129-139, 2004.

MALHOTRA, N. K. Pesquisa de marketing: uma orientação aplicada. Porto Alegre: Bookman, 2001.

NASH, John Forbes Jr. No-Cooperative Games. PhD Dissertation, Princeton University, 1950.

ONU, Organização das Nações Unidas - para agricultura e alimentação. Extraído via <http//:www.fao.org.br>, em 23 de abril de 2009.

PINHO, D. B. Economia e Cooperativismo. São Paulo: Saraiva, 1997.

Revista de Gestão Social e Ambiental - RGSA, São Paulo, v. 5, n. 2, p. 187-210 mai./ago. 2011. 
REBOUÇAS, A. C. Águas Doces no Brasil. São Paulo-SP: Escrituras, 1999.

SAAE, Serviço Autônomo de Água e Esgoto. Extraído via :<http//:www.saaecapivari.sp.gov.br>, em 22 de fevereiro de 2009.

SANTOS, J. A. A. Contratos de Concessão de Serviço Público. São Paulo: Jurua Editora, 2004.

SCHELING, T. The Strategy of Conflict-Prospectus for a Reorientation of Games Theory. The Journal of Conflict Resolution, p. 203-264, 1958.

SILVA, E. J. Concessão e Permissão no Serviço Público. São Paulo: Mizuno, 2005.

TILLES, S. How to Evaluate Corporate Strategy. Havard Business Review, july-august, p. 111$121,1978$.

TRIVERS, R. L. Parental investment and sexual selection. In: B. Campbell (org.), Sexual selection and descent of man, 1871-1971. Chicago, Aldine, p. 136-170.

TUCCI, C. E. M. Gestão da Água no Brasil. Brasília: Unesco, 2003.

TUNDISI, J. G. Água no século XXI: Enfrentando a Escassez. São Carlos-SP: Rima, IIE, 2003.

VARGAS, M. O Gerenciamento Integrado de Recursos Hídricos. Campinas-SP: Nepam, 1999.

Data do recebimento do artigo: 29/09/2010

Data do aceite de publicação: 09/07/2011

Revista de Gestão Social e Ambiental - RGSA, São Paulo, v. 5, n. 2, p. 187-210 mai./ago. 2011. 